\title{
A new observation on abnormal development in benthic foraminifers: Peneroplis pertusus (Forskål) - Peneroplis planatus (Fichtel and Moll) togetherness
}

\author{
Engin Meriç ${ }^{1}$, Mehmet Baki Yokeş ${ }^{2}$, Niyazi Avşar ${ }^{3}$ \& Cüneyt Bircan ${ }^{4}$ \\ 1 Moda Hüseyin Bey Sokak No: 15/4 34710 Kadıköy-Istanbul, Turkey. \\ 2 Haliç University, Department of Molecular Biology and Genetics, Bomonti, 34381, İstanbul, Turkey. \\ 3 Çukurova University, Department of Geological Engineering, 01330 Balcalı, Adana, Turkey. \\ 4 Balıkesir University, Department of Geological Engineering, 10165 Balıkesir, Turkey.
}

Correspondence

M.B. Yokeş

E-mail: bakiyokes@halic.edu.tr bakiyokes@turk.net

Received: 24 February 2012

Accepted: 23 July 2012

Published on-line: 31 July 2012

\section{Resumen}

Nueva observación de desarrollo anómalo en foraminíferos bentónicos: unión de Peneroplis pertusus (Forskål) - Peneroplis planatus (Fichtel and Moll)

Se ha investigado la agrupación de foraminíferos alrededor de un surgimiento submarino en la bahía de llica, (Çeşme, Esmirna). Se observó una fauna rica de foraminíferos, dominada por Penerólidos. Los individuos con morfología anormal fueron comunes en 8 géneros y 11 especies de Penerólidos. Se observó por primera vez la unión de Peneroplis pertusus (Forskål) y Peneroplis planatus (Fichtel and Moll).

Palabras clave: Peneróplidos, Mediterráneo, Bahía de llica, Turquía.

\begin{abstract}
Benthic foraminifer assemblages around a submarine spring in llıca Bay (Çeşme, Izmir) have been investigated. A rich foraminiferal fauna, dominated by Peneroplids were observed. Indviduals with abnormal test morphology was also common in 8 genera and 11 species of Peneroplids. Peneroplis pertusus (Forskål) and Peneroplis planatus (Fichtel and Moll) togetherness was observed for the first time.
\end{abstract}

Key words: Peneroplids, Mediterranean, Ilıca Bay, Turkey.

\section{Introduction}

Alterations and rapid changes in ecological parameters, such as salinity variations, temperature, solubility of calcium carbonate, dissolved oxygen, illumination, anthropogenic heavy metal pollution or heavy metals carried by groundwater are suggested to cause abnormal test development in foraminifers (Boltovskoy et al. 1991, Almogi-Labin et al. 1992, Yanko et al. 1998, Stouff et al., 1999a, 1999b, Geslin et al. 2000, 2002, Elberling et al. 2003). Abnormal test morphology have been reported from many locations world- wide (Cushman 1929, Cimerman and Langer 1991, Loeblich and Tappan 1994) and are known to be common in certain foraminifer genera and species (Geslin et al. 1998, Stouff et al. 1999a, 1999b).

Besides the morphological abnormalities, twins and triplets are common anomalies observed in benthic foraminifera. Conjoined twin, triplet and quadruplet individuals have been reported from Turkish coasts (Meriç 1996, Meriç et al. 2008a). The most striking abnormality was the conjoined twins formed by two different species, such as twins of Peneroplis pertusus-Cosci- 
nospira hemprichii, Peneroplis planatus-Coscinospira hemprichii and Vertebralina striata-Coscinospira hemprichii (Sellier de Civrieux, 1970; Meriç et al. 2005, 2008a, 2008b, 2009a).

In the frame work of this study, foraminiferal assemblage around a submarine spring in Ilica Bay (Çeşme, İzmir) was investigated. Besides a rich foraminiferal fauna, a twin of Peneroplis pertusus-Peneroplis planatus was observed for the first time.

\section{Material and methods}

The spring is located in Ilica Bay, on the northwestern of Karaburun Peninsula, the coordinates are $0444185 \mathrm{E}$ and $4240949 \mathrm{~N}$. The spring was taken as the center and a total of 38 recent sediment samples were collected at different points on three lines, A $\left(210^{\circ} \mathrm{N}\right), \mathrm{B}(120 \mathrm{~N})$ and $\mathrm{C}\left(290^{\circ} \mathrm{N}\right)$ directions. Sediment samples were collected at each $5,10,15,20,25,30,35,40,45,50,60,70$, 80,90 and $100 \mathrm{~m}$ distances according to the spring. But, because of a jetty, samples beyond 40 $m$ could not be obtained on line A (Fig. 1).

5 grams of wet sediment samples were weighed and treated with $10 \% \mathrm{H}_{2} \mathrm{O}_{2}$ for 24 hours. The samples were washed with pressurized water on 0.063 sieve and dried at $50{ }^{\circ} \mathrm{C}$ oven. The dried samples were further sieved with $2.00,1.00$, $0.500,0.250,0.125 \mathrm{~mm}$ mesh sizes. The foraminifer individuals were separated under binocular microscope.

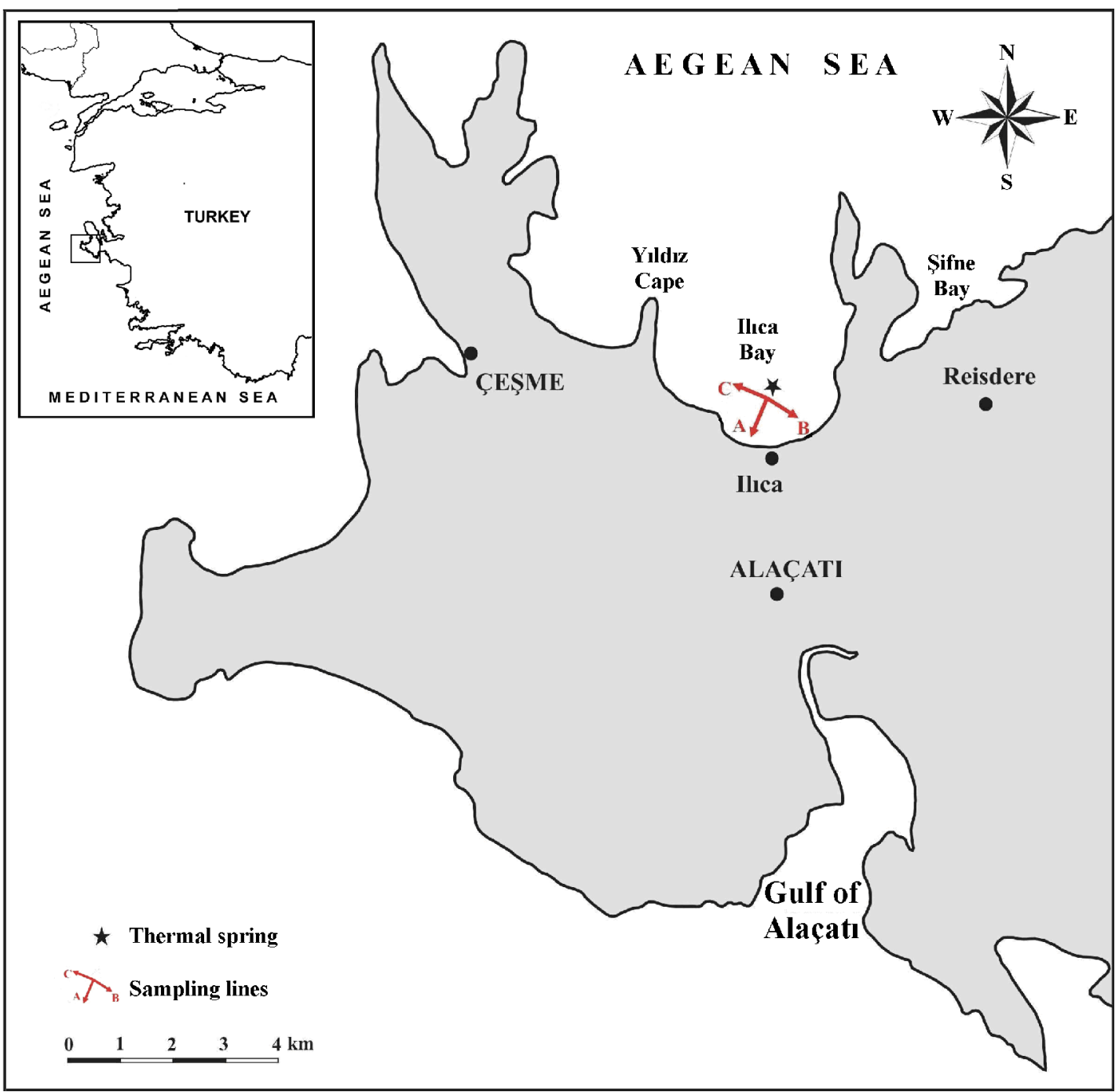

Figura 1. Área de estudio

Figure 1. Location of the study area. 


\section{Results}

\section{Foraminiferal assemblage}

45 genera and 80 species of benthic foraminifer species were identified in 38 samples; Textularia bocki Höglund, Spirillina vivipara Ehrenberg, Vertebralina striata d'Orbigny, Nodopthalmidium antillarum (Cushman), Nubecularia lucifuga Defrance, Adelosina carinata-striata Wiesner, A. cliarensis (Heron-Allen and Earland), A. mediterranensis (Le Calvez J. and Y.), Spiroloculina angulosa Terquem, S. antillarum d'Orbigny, S. ornata d'Orbigny, Siphonaperta agglutinans (d'Orbigny), S. aspera (d'Orbigny), Cycloforina contorta (d'Orbigny), C. villafranca (Le Calvez J. and Y.), Lachlanella variolata (d'Orbigny), Massilina gualteriana (d'Orbigny), M. secans (d'Orbigny), Quinqueloculina berthelotiana d'Orbigny, $Q$. bidentata d'Orbigny, $Q$. jugosa Cushman, $Q$. laevigata d'Orbigny, Q. lamarckiana d'Orbigny, Q. seminula (Linne), Miliolinella elongata Kruit, M. labiosa (d'Orbigny), M. subrotunda (Montagu), M. webbiana (d'Orbigny), Pseudotriloculina laevigata (d'Orbigny), P. oblonga (Montagu), $P$. rotunda (d'Orbigny), $P$. sidebottomi (Martinotti), Triloculina bermudezi Acosta, T. cf. fichteliana d'Orbigny, T. marioni Schlumberger, T. scheriberiana d'Orbigny, Sigmoilinita costata (Schulmberger), S. edwardsi (Schlumberger), $A r-$ ticulina carinata Wiesner, Parrina bradyi (Millet), Euthymonacha polita (Chapman), Coscinospira acicularis (Batsch), C. hemprichii Ehrenberg, Laevipeneroplis karreri (Wiesner), Peneroplis arietinus (Batsch), P. pertusus (Forskål), P. planatus (Fichtel and Moll), Amphisorus hemprichii Ehrenberg, Sorites orbiculus Ehrenberg, Polymorphina sp.3, Polymorphina sp.5, Polymorphina sp.7, Brizalina spathulata (Williamson), Reussella spinulosa (Reuss), Neoeponides bradyi Le Calvez, Gavelinopsis praegeri (Heron-Allen and Earland), Neoconorbina terquemi (Rzehak), Rosalina bradyi Cushman, R. globularis d'Orbigny, Pararosalina cf. dimorphiformis $\mathrm{McCul}$ loch, Planoglabratella opercularis (d'Orbigny), Cyclocibicides vermiculatus (d'Orbigny), Lobatula lobatula (Walker and Jacob), Planorbulina mediterranensis d'Orbigny, Cibicidella variabilis (d'Orbigny), Cymbaloporetta plana (Cushman), C. squammosa (d'Orbigny), Miniacina miniacea (Pallas), Asterigerinata mamilla (Williamson), Nonion depressulum (Walker and Jacob), Ammo- nia compacta Hofker, A. parkinsoniana (d'Orbigny), A. tepida Cushman, Challengerella bradyi Billman, Hottinger and Oesterle, Cribrodelphidium poeyanum (d'Orbigny), Porosononion subgranosum (Egger), Elphidium aculeatum (d'Orbigny), E. advenum (Cushman), E. complanatum (d'Orbigny), E. crispum (Linne), E. depressulum (Cushman), Elphidium sp. (Meriç and Avşar 2001, Meriç et al. 2002a, 200b, 2003a, 2003b, 2004, 2008c, 2009b). Nine of these species were Indo-Pacific originated.

\section{Abnormal foraminifers}

Peneroplids were found to be dominant in the investigated assemblages. Accordingly, abnormal test morphology was observed in the genera and species of this group. The test abnormalities were observed in 8 genera and 11 species, Vertebralina striata d'Orbigny, Spiroloculina angulosa Terquem, Coscinospira acicularis (Batsch), C. hemprichii Ehrenberg, Laevipeneroplis karreri (Wiesner), Peneroplis arietinus (Batsch), P. pertusus (Forskål), P. planatus (Fichtel and Moll), Sorites orbiculus Ehrenberg, Lobatula lobatula (Walker and Jacob), Cibicidella variabilis (d'Orbigny). However, the most abundant two genera which showed test abnormality were Coscinospira and Peneroplis, and the five species were Coscinospira acicularis (Batsch), C. hemprichii Ehrenberg, Peneroplis arietinus (Batsch), P. pertusus (Forskål), and P. planatus. (Fichtel and Moll). The togetherness between Peneroplis pertusus-Peneroplis planatus was observed for the first time (Fig. 2).

\section{Discussion}

Morphological abnormalities of foraminifer tests are considered to be indicators of stressed environments, and some species are used as bioindicators for anthropogenic pollution. However, it has been shown that the environmental stress may also be exerted by natural factors such as, hypersalinity, periodical acidification and strong hydrodynamics. Short-term changes in the salinity of seawater could result in morphological anomalies in benthic foraminifer tests (Geslin et al. 2002, Nigam et al. 2006, Meriç et al. 2008d). Thus, high ratios of abnormal to normal tests can also be observed in environments protected from human impact. 

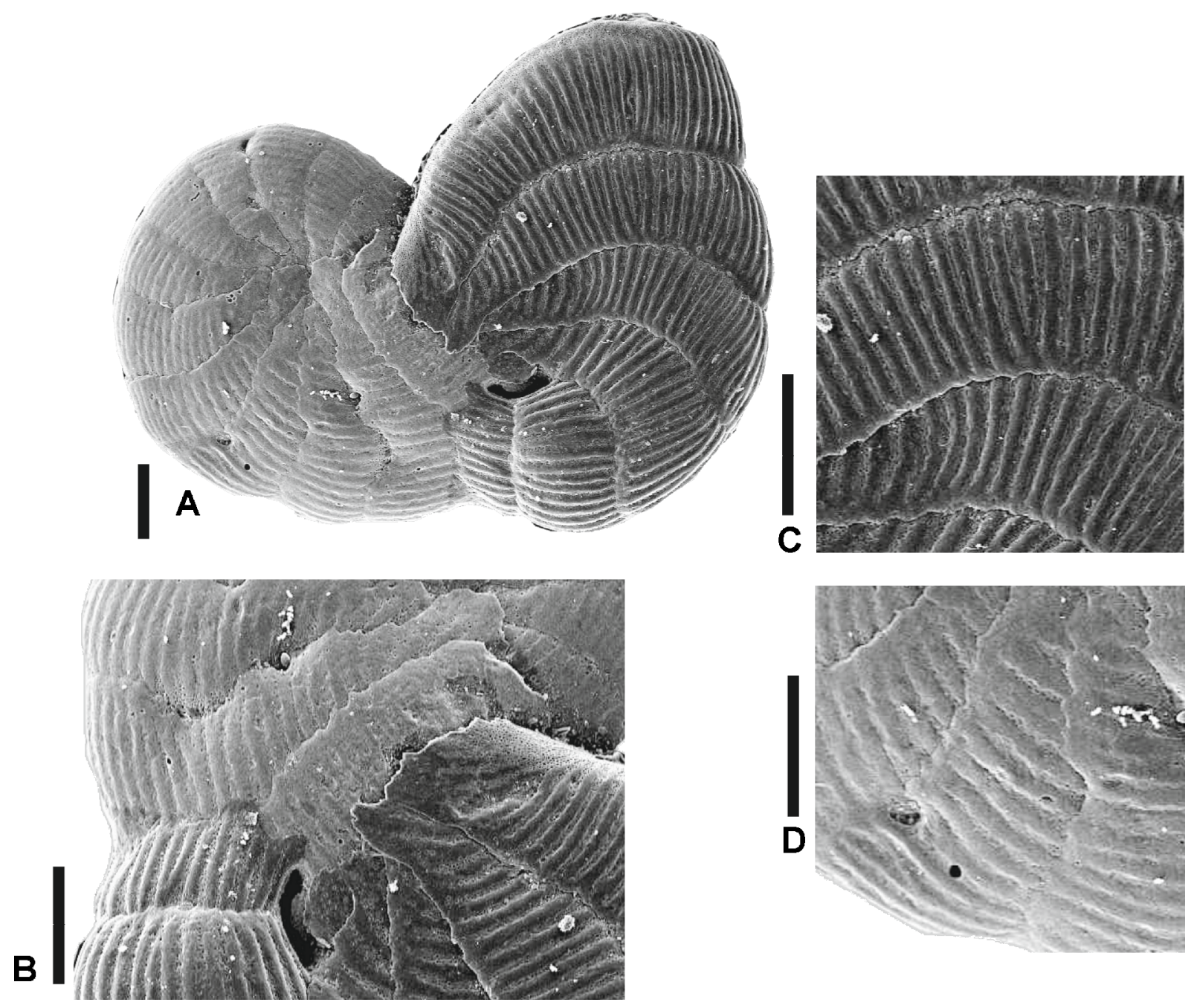

Figura 2. Unión de Peneroplis pertusus (Forskål) y Peneroplis planatus (Fichtel and Moll). A. Visión externa. B. Zona de unión de Peneroplis planatus (Fichtel and Moll) - Peneroplis pertusus (Forskål). C. Primer plano de Peneroplis planatus (Fichtel and Moll). D. Primer plano de Peneroplis pertusus (Forskål). C-90 m, Bahía de Ilica, Çeşme, Esmirna, Turquía. Barra de escala 100 $\mu \mathrm{m}$.

Figure 2. Peneroplis pertusus (Forskål) and Peneroplis planatus (Fichtel and Moll) togetherness. A. External view. B. Peneroplis planatus (Fichtel and Moll) - Peneroplis pertusus (Forskål) attachment site. C. Peneroplis planatus (Fichtel and Moll) close up view. D. Peneroplis

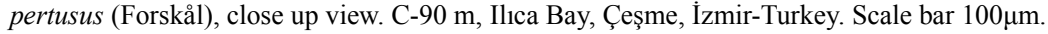

In this study a rich foraminiferal assemblage, represented by 48 genera and 80 species were observed. Morphologically abnormal individuals were also abundantly observed, mainly in Peneroplids. Examples of abnormal togetherness in Peneroplidae between Coscinospira hemprichii-Peneroplis pertusus, Coscinospira hemprichii-Peneroplis planatus and Vertebralina striata-Coscinospira hemprichii have been previously reported (Meriç, et al., 2008b; Meriç et al., 2009a). However, the specimen from Ilica Bay presents togetherness between Peneroplis pertusus-Peneroplis planatus (Fig. 2.)

\section{Conclusion}

The reproduction methods of the recent foramini- fers, schizogony and gamogony, have been studied by many researchers (Le Calvez, 1950, 1953; Grassé, 1953; Berthold, 1971; Röttger and Spindler, 1976). Schizogony is asexual production of macrospheric individuals from microspheric ones which takes place in cold seasons. Alternatively, gamogony is the production of microspheric individuals from the fusion of the gametes of two parental individuals, which is observed in summer. Abnormal individuals with morphological characteristics of two separate species are very rare events, which may not only be formed by pollution but also by chance. In this case a juvenile of Peneroplis planatus might have been fused with Peneroplis pertusus juvenile, or the Peneroplis planatus juvenile might have been attached to the aperture of a dead Peneroplis pertusus indi- 
vidual and have been grown on it. Laboratory experiments or genetic analysis may solve the mystery of abnormal togetherness among different species of foraminifera.

\section{Acknowledgements}

Authors would like to thank Nihat BOZDOĞAN and Tuğrul TÜZÜNER (T.P.A.O. Research Center) for SEM microphotography (Jeol JSM-6490).

\section{References}

Almogi-Labin A, Perelis-Grossovicz L \& Raab M. 1992. Living Ammonia from a hypersaline inland pool, Dead Sea Area, Israel. Journal of Foraminiferal Research 22: 257-266.

Berthold Wu. 1971. Untersuchungen über die sexuelle Differenzierung der Foraminifere Patellina corrugata Williamson mit einem Beitrag zum Entwicklungsgang und Schalenbau. Archiv für Protistenkunde 113: 147-184.

Boltovskoy E, Scott DB and Mediol FS. 1991. Morphological variations of benthic foraminiferal tests in response to changes in ecological parameters: a review. Journal of Paleontology 65: 175-185.

Cimerman F \& Langer MR 1991. Mediterranean foraminifera. Ljubljana: Slovenska Akademija Znanosti in Umetnosti, Akademia Scientiarum et Artium Slovenica, 118 pp., 93 plts.

Cushman JA. 1929. The foraminifera of the Atlantic Ocean. Part 6, Miliolidae, Opthalmidiidae and Ficherinidae. Bulletin of U. S. National Museum, 104 (6): 129 p., 22 pls., Washington.

Elberling B, Knudsen KL, Kristansen PH \& Asmund G. 2003. Applying foraminiferal stratigraphy as a biomarker for heavy metal contamination and mining impact in a fiord in West Greenland. Marine Environmental Research 55: 235-256.

Geslin E, Debenay J-P \& Lesourd M. 1998. Abnormal wall textures and test deformation in Ammonia (hyaline foraminifer). Journal of Foraminiferal Research, 28 (2): 148-156.

Geslin E, Stouff V, Debenay J-P \& Lesourd M. 2000. Environmental variation test abnormalities. Environmental Micropaleontology 15: 191-215. In Martin R.E. (ed.) Topics in Geobiology.

Geslin E, Debenay J-P, Duleba W \& Bonetti C. 2002. Morphological abnormalities of foraminiferal tests in Brizalian environments; comparison between polluted and non-polluted areas. Marine Micropaleontomlogy 45: 151-168.

Grassé P-P. 1953. Traité de zoologie anatomie, sytématique, biologie, 1. Protozoaires : rhizopodes, actinopodes, sporozoaires, cnidosporidies. Paris: Masson et Cie Editeurs.

Le Calvez J. 1950. Recherches sur les foraminiferes-II. Place de la meiose et sexualité. Archive Zoologie Experimentale 87 : 211-243.
Le Calvez J. 1953. Ordre des foraminiferes. In Grassé P.P. (ed.) Traité de zoologie: anatomie, systematique, biologie. Volume $1, \mathrm{~N}^{\circ}$ 2. Paris: Masson: 149-265.

Loeblich Jr AR \& Tappan H. 1994. Foraminifera of the Sahul Shelf and Timor Sea. Cushman Foundation for Foraminiferal Research. Spacial Publication No: 31,663 p., 63 pls

Meriç E. 1996. Twin forms in foraminifera from the Quaternary sediments of Gulf of Izmit (Turkey). Revue de Paléobiologie 15: 461-467.

Meriç E \& Avşar N. 2001. Benthic foraminiferal fauna of Gökçeada Island (Northern Aegean Sea) and its local variations. Acta Adriatica, 42 (1): 125-149.

Meriç E, Avşar, N \& Nazik A. 2002a. Bozcaada (Kuzey Ege Denizi) bentik foraminifer ve ostrakod faunası ile bu toplulukta gözlenen yerel değişimler. Ç. Ü. Yerbilimleri (Geosound), 40-41: 97-119, Adana.

Meriç E, Avşar N \& Bergin F, 2002b. Midilli Adası (Yunanistan-Kuzeydoğu Ege Denizi) bentik foraminifer faunası ve bu toplulukta gözlenen yerel değişimler. Ç. Ü. Yerbilimleri (Geosound), 40-41: 177-193, Adana.

Meriç E, Avşar N, Bergin F \& Barut IF. 2003a. Edremit Körfezi (Kuzey Ege Denizi) güncel çökellerindeki bentik foraminifer topluluğu ile ekolojik koşulların incelenmesi. Ç. Ü. Yerbilimleri (Geosound), 43: 169182, Adana.

Meriç E, Avşar N, Bergin F \& Barut IF. 2003b. Dikili Körfezi'nde (Kuzeydoğu Ege Denizi) bulunan üç anormal bentik foraminifer örneği: Peneroplis planatus (Fichtel ve Moll), Rosalina sp. ve Elphidium crispum (Linné) hakkında. M. T. A. Dergisi: 127, 6781, Ankara.

Meriç E, Avşar N \& Bergin F. 2004. Benthic foraminifera of Eastern Aegean Sea (Turkey) Systematics and Autoecology. Chamber of Geological Engineers of Turkey and Turkish Marine Research Foundation, Publication No: 18, 306 p., 33 plts, Istanbul.

Meric E, Görmüs M, Nielsen JK, Avşar N \& Ünsal I. 2005. Significance of rare reproduction occurrences among recent nodosariids and other benthic foraminifera. Anales de Biologia 27: 85-108.

Meriç E, Görmüş M, Avşar N, Yokes MB \& Dinçer F. 2008a. Twin, triplet and quadruplet teratogens in benthic foraminifera from Antalya. Micropaleontology 54: 293-306.

Meriç E, Yokeş MB, Nielsen JK, Görmüş M, Avşar N \& Dinçer F. 2008b. Abnormal formations in Peneroplids: Peneroplis-Coscinospira togetherness. Anales de Biologia, 30: 1-7.

Meriç E, Avşar N, Yokeş B \& Dinçer F. 2008c. Alibey ve Maden adaları (Ayvalık-Balıkesir) yakın çevresi bentik foraminiferlerinin taksonomik dağılımı. M.T.A. Dergisi, 137: 49-65, Ankara.

Meriç E, Avşar N, Nazik A, Tunoğlu C, Yokeş B, Barut IF, Yücesoy-Eryılmaz F, Tuğrul $B$, Görmüş $M$. Öncel MS, Orak H, Kam E \& Dinçer F. 2008d. Saros Körfezi (Kuzey Ege Denizi) Harmantaşı Mevkii sualtı yükseltisi çevresinin foraminifer ve ostrakod faunası ile bu alandaki kaynakların fauna üzerine etkisi hakkında bulgular. MTA Dergisi 136: 63-83. 
Meriç E, Yokeş, MB, Avşar N, Bircan C. 2009a. A new observation of abnormal development in benthic foraminifers: Vertebralina-Coscinospira togetherness. Marine Biological association of the United Kingdom, 2, e167: 1-6.

Meriç E, Avşar N, Mekik F, Yokeş B, Barut IF, Dora Ö, Suner F, Yücesoy-Eryılmaz F, Eryılmaz M, Dinçer F, Kam E. 2009b. Alibey ve Maden adaları (AyvalıkBalıkesir) çevresi genç çökellerinde gözlenen bentik foraminifer kavkılarındaki anormal oluşumlar ve nedenleri. Türkiye Jeoloji Bülteni, 52 (1): 31-84, Ankara.

Nigam R, Saraswat R \& Kurtarkar SR. 2006. Laboratory experiments to study the effects of salinity variations on benthic foraminiferal species-Pararotalia nipponica (Asano). Journal of the Geological Society of India 67: 41-46.

Röttger R \& Spindler M. 1976. Development of Heterostegina depressa individuals (Foraminifera, Nummulitidae) in laboratory cultures. In Schafer C.T. and Pelletier B.R. (eds) First international sympo- sium on benthonic foraminifera of continental margins. Halifax, NS: Maritime Sediments Special Publication 1: 81-87.

Sellier De Civrieux J M. 1970. Mutaciones recientes del genero Peneroplis $2008 \mathrm{f}$. relaciones filogenéticas con otros Soritidae. Revista Española de Micropaleontología, 2 (1): 5-12.

Stouff V, Debenay J-P \& Lesourd M. 1999a. Origin of double and multiple tests in benthic foraminifera: observations in laboratory cultures, environments. Marine Micropaleontology 36: 189-204.

Stouff V, Geslin E, Debenay J-P \& Lesourd M. 1999b. Origin of morphological abnormalities in Ammonia (Foraminifera): studies in laboratory and natural environments. Journal of Foraminiferal Research 29: 152-170.

Yanko V, Ahmad M \& Kaminsky M. 1998. Morphological deformities of benthic foraminiferal tests in response to pollution monitoring. Journal of Foraminiferal Research 28: 177-200. 